\title{
Lymphodepletional Strategies in Transplantation
}

\author{
Eugenia Page, Jean Kwun, Byoungchol Oh, and Stuart Knechtle \\ Department of Surgery, Division of Transplantation, Emory University School of Medicine, \\ Atlanta, Georgia 30322 \\ Correspondence: stuart.knechtle@emoryhealthcare.org
}

\begin{abstract}
Because lymphocytes were shown to mediate transplant rejection, their depletion has been studied as a mechanism of preventing rejection and perhaps inducing immunologic tolerance. Agents that profoundly deplete lymphocytes have included monoclonal antibodies, cytotoxic drugs, and radiation. We have studied several such agents but focused on antibodies that deplete not only peripheral blood lymphocytes, but also lymph node lymphocytes. Depletion of lymph node T lymphocytes appears to permit peripheral tolerance at least for $\mathrm{T}$ cells in animal models. Nevertheless, B-cell responses may be resistant to such approaches, and $\mathrm{T}$ memory cells are likewise relatively resistant to depleting antibodies. We review the experimental and clinical approaches to depletion strategies and outline some of the pitfalls of depletion, such as limitations of currently available agents, duration of tolerance, infection, and malignancy. It is notable that most tolerogenic strategies that have been attempted experimentally and clinically include depleting agents even when they are not named as the underlying strategy. Thus, there is an implicitly acknowledged role for reducing the precursor frequency of donor antigen-specific lymphocytes when approaching the daunting goal of transplant tolerance.
\end{abstract}

Intense immunosuppressive treatment at the time of transplantation is categorized as an induction regimen in organ transplantation. The goals of induction therapy in transplantation have evolved from preventing acute rejection to allowing lower doses of conventional immunosuppression and eventually inducing T-cell nonresponsiveness, also known as operational tolerance (Orlando et al. 2010). Induction therapy has been widely used in organ transplantation, involving $83 \%$ of renal transplant and $45 \%$ of heart transplant recipients in the United States in 2011 (Annual Report of the U.S. Organ Procurement and Transplantation Network and the
Scientific Registry of Transplant Recipients 2011). The use of depletional agents as an induction therapy also has been growing; 59\% of adult kidney transplant recipients and 18\% of adult heart transplant recipients now receive lymphodepletion. Generally, depleting antibodies activate the classical complement cascade upon binding to the target antigen and induce complement-mediated cell lysis of cells expressing target antigen. Furthermore, phagocytic cells with Fc receptor (FcR) preferentially engulf antibody-coated cells through ACCC (antibody-dependent cell cytotoxicity). However, other modes of action could also induce

Editors: Laurence A. Turka and Kathryn J. Wood

Additional Perspectives on Transplantation available at www.perspectivesinmedicine.org

Copyright (C) 2013 Cold Spring Harbor Laboratory Press; all rights reserved; doi: 10.1101/cshperspect.a015511

Cite this article as Cold Spring Harb Perspect Med 2013;3:a015511 
E. Page et al.

lymphocytic depletion, such as limiting survival factors of target cells.

Lymphocyte depletion prior to or beginning at the time of transplantation is beneficial in reducing maintenance immunosuppression (Calne et al. 1998, 1999; Swanson et al. 2002; Kirk et al. 2003; Starzl et al. 2003; Torrealba et al. 2003). Many depleting agents have been studied in animal models and clinical trials, and have been proven efficacious in reducing the rate of acute rejection when combined with maintenance regimens. Indeed, near-tolerance states were induced in many animal models. We showed, for example, that lymphodepletion by anti-CD3 immunotoxin (FN18-CRM9) prolongs renal allograft survival in the nonhuman primate renal transplantation model, but when combined with other immunosuppressive regimens it can induce long-term metastable tolerance (Torrealba et al. 2003, 2004). In human patients, toxicities of chronic calcineurin inhibitor use support the clinical need for depletional strategies (Torrealba et al. 2006). Depleting agents applied in conjunction with CNIs have shown fewer incidents of CNI-related side effects with similar outcomes in preventing acute rejection (Alexander et al. 2006).
This article provides an overview of lymphodepletion in organ transplantation (Fig. 1). We will discuss small and large animal transplantation models using depletional approaches, agents used in the clinic, and challenges to lymphodepletion, including protective immunity, homeostatic proliferation of recalcitrant memory populations, and humoral responses.

\section{LYMPHODEPLETION IN MOUSE MODELS}

The large precursor frequency of allospecific $\mathrm{T}$ cells among host $\mathrm{T}$ cells poses a significant challenge for transplantation. For that reason, lymphodepletion has become a common immunosuppressive strategy at the time of solid organ transplantation (Kwun et al. 2012a). Although this strategy has helped improve early graft survival, long-term outcomes after depletion are still afflicted with challenges. Animal models have been of great importance in exploring transplant immunology. The rodent model in particular provides essential and critical insight on the basic mechanisms of lymphocyte depletion and homeostasis for field of transplantation, although there are gaps between clinical conditions and animal models (Kwun et al.

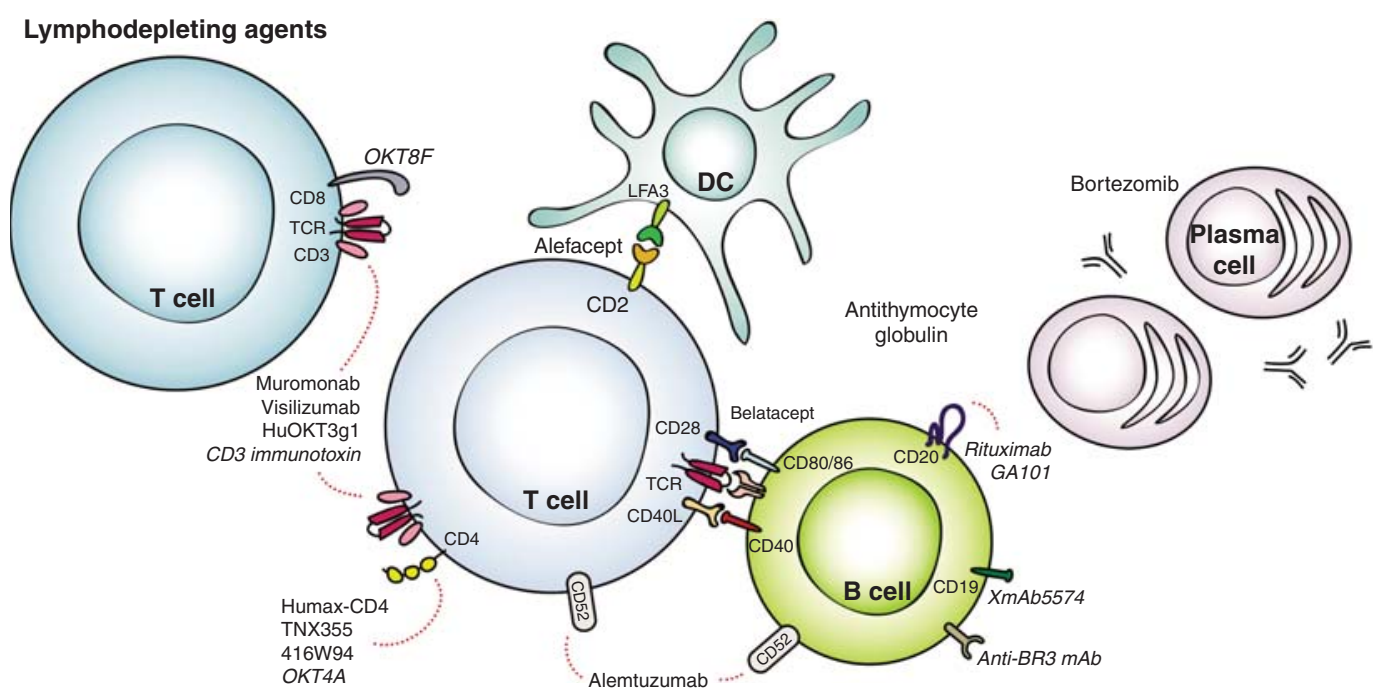

Figure 1. Lymphodepleting agents. Portrayed in this figure are preclinical and clinical agents found to have depleting properties on T cells, B cells, and plasma cells. The dotted lines indicate target specificities for the agents. 
2012a). Here we will discuss depletion of T and B cells, plasma cells, and natural killer (NK) T cells in rodent models.

\section{T-Cell Depletion}

The first antibodies used since the 1960s, antithymocyte globulin (ATG) induces a rapid and profound lymphodepletion. ATG-induced lymphocyte depletion not only resulted in transplant tolerance in several rodent transplant models but also enhanced regulatory T-cell (Treg) number and function (Feng et al. 2008; Joseph et al. 2012; Shi et al. 2012). Hongo et al. further described that in a combined bone marrow and heart transplant murine model, Treg production of IL-10 and up-regulation of PD-1 was enhanced by IL-4 produced by host natural killer cells (Hongo et al. 2012). Despite the development of newer antibodies, ATG continues to be investigated in murine models today.

The first monoclonal antibody, OKT3, was produced in the late 1970s (Kung et al. 1979), and many researchers have used anti-CD3 $\mathrm{mAb}$ for inducing transplant tolerance. The administration of anti-CD3 mAb led to the rapid depletion of T cells from peripheral blood and suppression of heart and islet graft rejection in the rodent model (Nicolls et al. 1993; Tang et al. 2003). However, depletion of $\mathrm{T}$ cells from the spleen and lymph nodes was both delayed and incomplete.

As helper CD4 T lymphocytes control humoral and cellular responses, targeting subpopulations using anti-CD4 antibodies appeared to be the best strategy to achieve tolerance to heart allografts in the rodent model (Pearson et al. 1993). Treatment with this monoclonal antibody rapidly depletes the recipient of circulating $\mathrm{CD} 4^{+} \mathrm{T}$ cells, and repopulation takes about 40-50 days. Their median survival time was over 60 days after transplant (Orosz et al. 1996). AntiCD4 antibodies depleted Tregs but not as efficiently as $\mathrm{CD} 4{ }^{+} \mathrm{CD} 25^{-}$cells, resulting in an enhanced peripheral $\mathrm{CD} 4{ }^{+} \mathrm{CD} 25^{+} / \mathrm{CD} 4^{+} \mathrm{CD} 25^{-}$ ratio and thus promoting tolerance (Yi et al. 2008). Cytotoxic CD8 T cells are highly aggressive toward allografts, but unlike CD4 T-cell de- pletion, the depletion of these cells by the antiCD8 antibody was not efficient in preventing acute rejection in rodent models.

Mouse T-cell depletion with anti-CD52 antibody alemtuzumab requires the use of human CD52 transgenic mice, in which hCD52 is expressed under the direction of the mouse CD2 promotor and thus only on T cells. Our murine experience with alemtuzumab showed profound peripheral T-cell depletion with the repopulation of $\mathrm{CD} 44^{\text {hi }} \mathrm{CD} 62 \mathrm{~L}^{\text {lo }}$ memory $\mathrm{T}$ cells. Despite complete T-cell repopulation by 10 weeks, treated animals showed no evidence of acute rejection, and showed excellent graft survival and function for more than 200 days. Half of the alemtuzumab recipients, however, showed alloantibody production and antibody-mediated chronic rejection (Kwun et al. 2012b). Furthermore, alloantibody-producing animals had increased allospecific B cells found in their spleens, as well as ongoing germinal center reactions represented by CD38-alloreactive B cells.

Other T-cell depleting agents targeting CD2 (Sido et al. 1998) and TCR $\alpha \beta$ (Heidecke et al. 1995) have resulted in long-term allograft survival. Sido et al. evaluated three anti-CD2 monoclonal and found that graft survival correlated with dose-dependent down-modulation of CD2, and that humoral responses were preserved. Heidecke et al. observed that, despite incomplete depletion of $\mathrm{CD}^{+}$cells, the $\alpha / \beta$ $\mathrm{T}$-cell receptor blockade was able to induce hyporesponsiveness in a murine heart transplant model after skin graft sensitization.

\section{B-Cell Depletion}

Agents that deplete B cells in human recipients, such as alemtuzumab and ATG, have limited efficacy at B-cell depletion in rodents. CD20 is expressed early in B-cell development, downregulates through maturation, and is then absent on mature plasma cells. Anti-CD20 mAB depletes mature, germinal center, and memory $B$ cells but does not affect plasma cell or serum IgG levels (DiLillo et al. 2008). In rodent models, mature B-cell depletion using anti-CD20 $\mathrm{mAb}$ had no effect on acute skin allograft rejec- 
E. Page et al.

tion and chronic renal rejection but inhibited the development of allospecific IgG (DiLillo et al. 2011). CD19 is expressed on memory B cells and short-lived plasma cells. Anti-CD19 antibody treatment has the effect of depleting B-cell subsets and some plasma cells resulted in enhanced allograft survival and a reduction in circulating allo-specific IgG in human CD19 transgenic mouse models (DiLillo et al. 2011).

\section{Plasma Cell Depletion}

Bortezomib is a proteasome inhibitor that selectively targets the 26s proteasome complex. Plasma cells produce large quantities of protein, a proportion of which will be misfolded and will require degradation and disposal by the proteasome. Inhibition of proteasome activity results in the accumulation of misfolded proteins and consequent apotosis of the plasma cell. In rodent transplant models, proteasome inhibition suppresses ongoing rejection and increases mean survival time after heterotropic heart transplantation, which suggests possible efficacy in transplantation (Luo et al. 2001).

Recent clinical data have shown acute cellular rejection after B-cell depletion with rituximab, suggesting positive or negative effects on graft rejection, depending on the nature of the allograft and response (Clatworthy et al. 2009). Because mature B-cell depletion with CD20 $\mathrm{mAb}$ will not be sufficient to prevent acute and chronic allograft rejection, new therapies such as CD19 mAb and the next generation of proteasome inhibitors may offer a new approach for depleting both B cells and plasma cells. For testing these agents to investigate their mechanisms, proper animal models will be needed due to constraints in strain and species specifics (Kwun et al. 2012b).

\section{NK Depletion}

NK cells are a subset of lymphocytes with cytokine-secreting and cytotoxic effector functions that respond to viral infection, cell stress, and tumors (Vivier et al. 2008). Defining the role of NK cells in transplantation is less clear because of evidence suggesting their involvement both in rejection and in tolerance. During acute rejection, graft infiltrating NK cells secrete chemokines that amplify local inflammation and IFN $\gamma$, which exacerbates allograft rejection and enhances T-cell-mediated immunity. Also, in murine heart transplant models, NK cell depletion has been shown to reduce alloantibodymediated chronic allograft vasculopathy (Hirohashi et al. 2012). Others have observed that NK cell-depleted recipients showed monocyte and macrophages infiltration in grafts (van der Touw et al. 2012).

\section{LYMPHODEPLETION IN NONHUMAN PRIMATES}

En route to clinical translation, lymphodepleting agents have been widely explored in nonhuman primate models of transplantation since the 1980s. Some depleting agents were used as primary induction agents whereas others were incorporated into a combination of therapeutic modalities for transplant tolerance induction. This section will focus on lymphodepletion by pharmacologic and biologic agents and not by virus- or retrovirus-mediated methods.

\section{Polyclonal Antibody Preparations}

Polyclonal antilymphocyte globulins, initially prepared from horses immunized with human spleens, thymus, and lymph nodes, have been used for immunosuppression in renal transplantation since the 1960s (Starzl et al. 1963, 1967; Najarian and Simmons 1971). A technology discovered in the 1890 s by Mechnikov (Gaber et al. 2010), the mechanisms of action of the modern preparations - rabbit and equine ATG-are vastly diverse due to target antigens that range from surface immune response antigens, costimulation markers, adhesion and trafficking molecules, and many more (Bonnefoy-Berard et al. 1991; Rebellato et al. 1994; Bourdage and Hamlin 1995; Mohty 2007). Preville et al. found that rabbit ATG-administered cynomolgus macaques showed a dose-dependent lymphodepletion in peripheral blood, axillary lymph nodes, and spleens but not in 
Lymphodepletional Strategies

thymuses (Preville et al. 2001). At very high doses $(20 \mathrm{mg} / \mathrm{kg})$, peripheral blood $\mathrm{T}$ counts dropped to zero within $2 \mathrm{~h}$ of the first ATG infusion.

Early nonhuman primate studies showed that combining ATG with other modalities could significantly increase allograft survival and immunologic unresponsiveness. Thomas et al. observed that kidney transplanted rhesus macaques receiving $50 \mathrm{mg} / \mathrm{kg}$ of rATG for 5 days followed by a single infusion of unfractionated donor bone marrow on day 12 experienced longterm survival past 248 days without evidence of graft versus host disease, infection, or rejection (compared to 35.8 days for rATG alone, $p<$ $0.001)$; a second donor bone marrow infusion on day 24 reversed the benefit, however, as the animals rejected with a mean graft survival time of 76.6 days (Thomas et al. 1983). In revisiting the ATG + dBM model, the group observed a reduced median survival of 70 days, still a considerable feat in the absence of chronic immunosuppression (Thomas et al. 1989).

Several groups have observed long-term graft acceptance when combining ATG with other modalities. Pearl et al. studied thymectomized cynomologus macaques depleted with rATG $(20 \mathrm{mg} / \mathrm{kg} \times 7$ days $)$, and found that antiCD154, sirolimus, and donor specific whole blood transfusion successfully inhibit the homeostatically proliferating memory T-cell response in the depleted animals to yield rejection-free survivals of $>300$ days (Pearl et al. 2007). Kawai et al. observed renal allograft tolerance in cynomolgus macaques achieving mixed chimerism after treatment with equine ATG $(50 \mathrm{mg} / \mathrm{kg} \times 3$ days), nonmyeloablative totalbody irradiation, thymic irradiation, and donor bone marrow infusion (Kawai et al. 1995). When anti-CD154 mAb was added to this regimen $(+\mathrm{CsA} \times 28$ days $)$, donor bone marrow engraftment was enhanced, leading to long-term renal allograft survival $>688$ days (Kawai et al. 2004). The further addition of humanized antiCD8 mAb (cM-T807) depleted remaining CD8 memory $\mathrm{T}$ cells and allowed for animals to achieve renal allograft tolerance (Koyama et al. 2007). Other groups have combined rATG with anti-CD20 mAb rituximab (Liu et al.
2007) or with sirolimus (Hirshberg et al. 2003) to prolong islet allograft survival in nonhuman primates.

\section{CD3 Immunotoxin}

In contrast to the wide heterogeneity of ATG's target specificities, the single antigen-specific antirhesus CD3 immunotoxin developed by Neville et al. (Neville et al. 1992) was pursued with much interest by our group and others (Knechtle 2001). The antirhesus monoclonal antibody FN18 conjugated with mutated diphtheria toxin CRM9 was able to deplete CD3 T cells by $2-3$ logs in peripheral blood and by 2 logs in lymph nodes, when we administered a three-day course to rhesus macaques (Knechtle et al. 1998). We observed long-term renal allograft acceptance (mean survival time, 614 days) with donorspecific tolerance confirmed by skin grafting in our long-term survivors; however, a high incidence of donor-specific alloantibodies (73\%) and chronic rejection (100\%) was also observed (Knechtle et al. 1997, 1998; Torrealba et al. 2003).

We ventured to investigate the activation of the humoral response and eventual chronic rejection in the FN19-CRM9 immunotoxin-treated animals, but the drug was replaced with a new recombinant immunotoxin (A-dmDT390scfbDb[C207]) because of production yield difficulties and potential immunogenicity of the former chemically conjugated construct (Ma et al. 1997; Kim et al. 2007; Wang et al. 2011). Although the use of the new immunotoxin provided profound peripheral T-cell depletion, the rapid proliferation of memory $\mathrm{T}$ cells prevented sustained graft survival. Tacrolimus and alefacept were added to target the memory $\mathrm{T}$ cells, which resulted in early and consistent alloantibody production and antibody-mediated graft injury in all treated macaques (Page et al. 2012). Nishimura et al. doubled the immunotoxin dose to $50 \mu \mathrm{g} / \mathrm{kg} \times 8$ doses and combined it with an anti-CD2 antibody in a GalT-KO pig-to-baboon thymokidney model, which led to the preservation of graft function but death due to pneumonia or heart failure at 15 and 23 days (Nishimura et al. 2011). 
E. Page et al.

\begin{abstract}
Alemtuzumab
Alemtuzumab (Campath-1H), a humanized IgG1 monoclonal antibody, targets the membrane glycoprotein CD52, resulting in profound and sustained T-cell depletion as well as transient depletion of B cells, macrophages, and natural killer cells (Hale 2001; Magliocca and Knechtle 2006). Its use in nonhuman primates has been limited as most Old World monkeys express CD52 also on red blood cells, potentially leading to lethal hemolytic anemia if administered the drug. Recently, van der Windt et al. evaluated an agglutination assay and identified cynomolgus macaques of Indonesian but not Chinese origin to be RBC-CD52 negative (van der Windt et al. 2010). As they achieved greater than $99.5 \%$ depletion of $\mathrm{T}$ and $\mathrm{B}$ cells with $20 \mathrm{mg} / \mathrm{kg}$ of alemtuzumab, this model provides opportunities to further investigate the drug in preclinical studies.
\end{abstract}

\section{Other T-Cell Depleting Agents}

The advent of monoclonal antibodies provoked much interest in the transplant community, with several studies applying depleting antibodies to T-cell targets (OKT3, OKT4, OKT8, and OKT11 to $\mathrm{CD} 3, \mathrm{CD} 4, \mathrm{CD} 8$, and $\mathrm{E}$ rosettes, respectively) in nonhuman primate models (Jonker et al. 1983; Letvin et al. 1985; Cosimi et al. 1990; Rao et al. 1991). These early monoclonal antibodies, namely OKT3, although effective at treating acute rejection, were associated with cytokine release syndrome, increased risk of posttransplant lymphoproliferative disease, and xenosensitization to its murine component (Chatenoud et al. 1990; Schroeder et al. 1990; Cherikh et al. 2003). To diminish the antimurine response, humanized chimeric preparations of several of the early monoclonal antibodies were developed and are still used in nonhuman primate studies today (Woodle et al. 1992; Delmonico et al. 1993; Engram et al. 2010).

Other depleting agents no longer used in human organ transplantation include alefacept (LFA3-Ig) and fingolimod (FTY720). The CD2specific fusion protein alefacept (LFA3-Ig), which selectively depletes memory $\mathrm{T}$ cells, has been used as adjunct immunosuppression in nonhuman primate models of cardiac, renal, and xenoislet transplantation (Kaplon et al. 1996; Weaver et al. 2009; Page et al. 2012; Thompson et al. 2012). Fingolimod, a sphingoside-1-phosphate receptor agonist administered orally, was found to effectively deplete $\mathrm{T}$ and $\mathrm{B}$ cells in baboons and cynomolgus macaques (Quesniaux et al. 1999, 2000), and prevent acute rejection in nonhuman primate renal, alloislet, and xeno-islet transplantation (Schuurman et al. 2002; Wijkstrom et al. 2004; Hering et al. 2006).

\section{B-Cell Depletion}

Several B-cell-targeting therapeutics have emerged over the last decade, as our understanding of the impact of $B$ cells on allograft rejection as well as transplant tolerance has increased (Redfield et al. 2011; Kwun et al. 2012a). These strategies may be of particular interest in the setting of T-cell depletion in which humoral immunity is often up-regulated. Their applications may also be extended to sensitized patients preand posttransplant.

The following agents targeting the B-cell surface molecules CD19 and CD20, costimulatory target CD40, and B-cell survival factors in the BAFF pathway have resulted in effective B-cell depletion. Rituximab (IDEC-C2B8), originally developed for B-cell lymphomas, has been used in several preclinical models, including islet cell transplantation (in combination with rATG), renal transplantation (with rATG, sirolimus, and donor bone marrow infusion), cardiac transplantation (with cyclosporine A), and pigto-baboon cardiac xenotransplantation (with rATG, splenectomy, and maintenance immunosuppression) (McGregor et al. 2005; Liu et al. 2007; Maki et al. 2008; Kelishadi et al. 2010). GA101, a humanized IgG1 to CD20, induced further B-cell depletion particularly in lymphoid tissues in cynomolgus macaques (Mossner et al. 2010). XmAb5574, an Fc-engineered antibody to CD19, showed sustained B-cell depletion to $<10 \%$ of baseline as well as transient NK cell depletion in cynomolguc macaques ( $\mathrm{Za}$ levsky et al. 2009). Although some anti-CD40 
antibodies are nondepleting, Chi220 administered to rhesus macaques showed near complete peripheral B-cell depletion (Pearson et al. 2002). $\mathrm{BR} 3$ is one of three receptors for the B-cell activating factor BAFF; humanized anti-BR3 antibodies reduced B-cell populations in peripheral blood as well as lymphoid tissues, but not as profoundly as anti-CD20 treatment (Lin et al. 2007).

\section{CURRENT LYMPHOCYTIC DEPLETION IN CLINIC}

Currently used antibodies to deplete immune cells in solid organ transplant patients include thymoglobulin (rabbit ATG, Genzyme), ATGAM (equine ATG, Pfizer), and alemtuzumab (Campath-1H). Another rabbit ATG is marketed in Europe by Fresenius. Alemtuzumab was bought by Sanofi in 2011 and is being remarketed at a higher price under the name Lemtrada. Thymoglobulin is approved by the U.S. Federal Drug Administration for treatment of acute renal allograft rejection but not as an induction agent nor for other organs, although the drug is commonly used for these other purposes. Alemtuzumab is approved for treatment of lymphoma but not for organ transplantation, and its ownership by more than four drug companies over the past 10 years and the economics of its development make it unlikely to receive regulatory approval in the near future for organ transplantation. Nevertheless, these two agents are commonly used, and there is considerable experience, especially in kidney transplantation, with both. The published data on both agents inform our use and practice, but they leave unclear the ideal dose, duration, and indications for depletional therapy despite extensive experience. According to the 2011 Annual Report of the Scientific Registry of Transplant Recipients (SRTR/OPTN), about $60 \%$ of renal transplant patients in the United States received a depleting agent at the time of transplantation in 2010.

As discussed with regard to nonhuman primate (NHP) depletional therapy, CD3-immunotoxin (CD3-IT), developed by Neville for NHP use, potently depletes not only peripheral blood $\mathrm{CD}^{+} \mathrm{T}$ cells, but also lymph node cells, within days. This agent (FN18 ${ }^{-}$CRM9) was in development by Novartis for human use with the intention of developing a genetically derived recombinant fusion protein, thus avoiding chemical conjugation of $\mathrm{CD} 3 \mathrm{mAb}$ and mutated diphtheria toxin (CRM9) and inevitable unconjugated products that would contaminate such a compound. However, this development project was finally aborted after the new constructs, such as a monovalent antibody fused to toxin, failed to have similar potency, binding properties, or stability compared to the NHP original construct, as discussed above. However, taking a cue from the remarkable ability of the CD3-IT depletion to promote tolerance, Calne revisited clinical use of Campath-1H, a potent anti-CD52 mAb produced by Herman Waldmann in the Cambridge, England pathology department (hence the name, with $\mathrm{H}$ for humanized). Calne wisely combined Campath$1 \mathrm{H}$ with low dose cyclosporine, aiming for near or "prope" tolerance in humans rather than a completely drug-free state. The data from the Cambridge kidney transplant experience with Campath-1H have been published with both early and long-term follow up, and indicate the safety of profound depletion from an infection and malignancy perspective and the ability of depletion to replace some degree of maintenance immunosuppression (Calne et al. 1998; Watson et al. 2005).

Studies by our group supported by the Immune Tolerance Network (ITN) in human kidney transplantation evaluated the ability of high dose alemtuzumab to achieve tolerance in 10 haploidentical living donors or other wellmatched renal transplant recipients. Although four of 10 patients achieved stable renal function for $>3$ years on rapamycin $1 \mathrm{mg}$ daily with levels $<4 \mathrm{ng} / \mathrm{ml}$, none of these patients totally withdrew immunosuppression. Another observation of this study was that most other patients (5/10) developed detectable donor-specific alloantibodies after the withdrawal of tacrolimus that occurred at 60 days in the protocol. This high incidence of alloantibodies was shown by our group in other studies to be driven by tacrolimus withdrawal and to correlate with high 
E. Page et al.

BAFF levels (Shapiro et al. 2008; Bloom et al. 2009; Ruhil et al. 2012). Nevertheless, this study suggests that well-matched kidney transplant patients treated with profound depletion in the setting of low dose tacrolimus, later weaned from tacrolimus, and then weaned to very low dose rapamycin may become unresponsive. Mechanistic assays are in the process of confirming the nature of the donor-specific unresponsiveness of these selected patients.

An ongoing study by Kirk reflects a modification of the ITN study above and substitutes belatacept for tacrolimus, perhaps an ideal combination that avoids the high alloantibody incidence associated with tacrolimus withdrawal and takes advantage of the known benefit of belatacept to prevent alloantibody. This study has been reported in abstract form (Kirk et al. 2011) and follow-up studies are in progress. Although it is too early to compare such a study to conventional therapy, results have been excellent; however, once again they show that complete drug withdrawal may not be advisable. The longer term outcomes of this study remain of high interest.

Perhaps the best and largest prospective, randomized study of alemtuzumab induction in renal transplantation was by Hanaway et al. (2011). This study compared alemtuzumab to anti-CD25 (Simulect) in low risk recipients and to thymoglobulin in high-risk recipients. All groups received maintenance immunosuppression with tacrolimus, mycophenolate, and steroids. The main findings were that alemtuzumab was associated with significantly less acute rejection compared to Simulect in low risk patients, but that there was no significant difference in acute rejection between the two high-risk groups (alemtuzumab vs. thymoglobulin). There were no significant differences in infection or side effects among the four groups.

Thymoglobulin induction in kidney transplantation continues to be used particularly for patients considered to be at higher than average risk of rejection. According to the SRTR 2011 annual report on kidney transplantation, abuse was driven by a publication from Brennan et al. (2006) comparing anti-CD25 induction to thymoglobulin, with slightly better results seen with depletion. Nevertheless, a recent trend toward less depletion and more reliance on tacrolimus and anti-CD25 reflects the relatively thin layer of objective data that show superiority of depletion for even the higher risk patients. Higher risk refers to retransplants, African-American recipients, and sensitized or previously sensitized but current cross-match negative recipients of renal allografts.

One of the lessons learned in the past 15 years about depletion induction therapy in renal transplantation is that whereas it clearly protects from acute rejection in the early posttransplant period, maintenance therapy is necessary during cell repopulation to particularly prevent $\mathrm{T}$ memory cells (Tmem) from driving rejection and alloantibody formation. As Pearl nicely showed, Tmem are particularly resistant to depletion and perhaps best controlled by calcineurin inhibitors (CNI) (Pearl et al. 2005). Thus, depletional strategies that have been most successful, such as the alemtuzumab/tacrolimus protocol described by Shapiro et al. (2007), rely on at least a low dose of CNI maintenance therapy. Similarly, thymoglobulin protocols typically use triple drug maintenance therapy with tacrolimus, mycophenolate, and steroids for higher risk patients (Gurk-Turner et al. 2008) with good results.

The long-term safety of depletion with respect to opportunistic infection (cytomegalovirus $[\mathrm{CMV}]$, other viral and fungal infections) and malignancy (posttransplantation lymphoproliferative disease $[\mathrm{PTLD}]$ ) depends on the agent used and the intensity and duration of therapy. Given the age-related senescence of the lymphocyte compartment, it would stand to reason that older patients would tolerate depletion less well than younger patients. Kirk et al. (2007) reported that in contrast to thymoglobulin and OKT3 that are associated with increased risk of PTLD, the cumulative experience with alemtuzumab did not suggest an increased risk of PTLD. However, repeated use of alemtuzumab in transplant patients to maintain a low white blood cell (WBC) count is not recommended and was associated with unacceptable side effects in a Minnesota experience with the drug (Nath et al. 2005). 
Use of depleting antibodies in liver transplantation continues at some centers although the majority of U.S. centers do not use any routine induction and only about $15 \%$ of recipients receive any induction antibody. Many centers add anti-CD25 induction for patients with renal dysfunction with the notion of delaying CNI introduction until renal function improves. Data from the University of Pittsburgh suggest that using alemtuzumab induction in hepatitis C-positive liver transplant recipients is associated with unacceptable outcomes and is ill-advised (Marcos et al. 2004). Other experiences with thymoglobulin induction in liver transplantation suggest that it does not reduce acute rejection incidence but increases the incidence of leukopenia (Boillot et al. 2009). A recent randomized controlled trial suggests that rather than depleting antibodies, lower dose tacrolimus in combination with everolimus spares renal function and effectively prevents rejection (De Simone et al. 2012). This strategy may be more effective than increasing the potency of induction immunosuppression by depletion in liver transplant patients who are often immunocompromised already from their illness.

\section{CHALLENGES IN LYMPHODEPLETION}

Although depletion is highly effective and increasingly used as an induction regimen, lymphodepletional agents are associated with several problems. As mentioned above, polyclonal preparations bring undesirable complications of transient cytokine release, viral reactivation, and antianimal antibody production. Although monoclonal OKT-3 solved some of these issues with polyclonal preparations, it was still subject to a significant antimouse response, as OKT3 is an entirely mouse-derived antibody (Webster et al. 2006). These xenogeneic antibodies can dramatically reduce the efficacy of these agents and extended/repeated use may lead to anaphylaxis and serum sickness (Prin Mathieu et al. 1997; Regan et al. 1997, 2001). The first dose of these antibodies can be followed by fevers, chills, and gastointestinal, respiratory, and cardiac complications, mostly due to the release of py- rogenic cytokines such as IL- 6 and TNF- $\alpha$ from target cell lysis (Debets et al. 1989; Chatenoud et al. 1990; Vallhonrat et al. 1999). Alternatively, these cytokines could be released by a transient activation of T cells before they undergo cell lysis (Hardinger 2006; Webster et al. 2006). This cytokine release syndrome can be limited by methylprednisolone. These adverse effects were much improved with the development of monoclonal antibodies and fusion proteins. To avoid xenogeneic antibody production, the gene fragment encoding xenogenic epitopes in the mAb may be exchanged with equivalent portions of human antibodies (Boulianne et al. 1984; Morrison et al. 1984). Other early complications, including cardiovascular and infectious deaths, correlate with lymphodepletion, but the interpretation of this relationship is confounded by the preferential use of antibodies in high-risk patients (Opelz 1995).

\section{Infectious Complications}

Patients with prolonged lymphopenia are more likely to develop serious infections, especially when depletion is combined with other immunosuppressants before or after transplantation. Polyclonal antibodies have been shown to increase reactivation and development of primary viral disease with cytomegalovirus, herpes simplex virus, Epstein-Barr virus (EBV), and varicella, which more likely represent intensive immunosuppression (Abbott et al. 2002; Gourishankar et al. 2004). More recent reports have shown no increased risk of cytomegalovirus (CMV) infection, possibly due to the proper usage of antiviral prophylaxis (Webster et al.2006). Although higher infection rates were observed in patients receiving thymoglobulin compared to nondepleting anti-CD25 mAb treated patients ( $85.8 \%$ vs. $75.2 \%, P=0.03$ ), a lower incidence of cytomegalovirus disease was documented from thymoglobulin treated patients $(7.8 \%$ vs. $17.5 \%, P=0.02$ ) (Brennan and Schnitzler 2008). Alemtuzumab did not show a significant risk of infection compared to thymoglobulin or basiliximab (Hanaway et al. 2011). Owing to its intensity on immunosuppression in general, lymphodepletion should be accompanied by 
E. Page et al.

broad prophylaxis to prevent opportunistic viral (cytomegalovirus and BK virus) and bacterial infections (urinary tract infection, pneumonia, and bacteremia) (Hibberd et al. 1992; Batiuk et al. 2002).

\section{Malignant Complications}

Early depletion approaches, such as polyclonal antibodies and OKT3, have been linked with the risk of developing posttransplantation lymphoproliferative disease (PTLD) when combined with maintenance immunosuppressants (Penn 1990; Malatack et al. 1991; MeierKriesche et al. 2002; Cherikh et al. 2003). In an exemplary analysis of 157 consecutive cardiac transplant recipients, a ninefold higher incidence of PTLD was observed in OKT-3 treated cardiac allograft patients. Furthermore, a doserelated risk was also observed, with more frequent PTLD observed in patients receiving a cumulative dose of OKT3 exceeding $75 \mathrm{mg}$ than in those who received a lower total dose (35.7\% vs. 6.2\%; $p<0.001$ ) (Swinnen et al. 1990). On the other hand, analysis of 207 patients with thymoglobulin did not reveal an association with an additional risk of malignancies (El-Hamamsy et al. 2005). Interestingly, alemtuzumab induction has also shown a low PTLD incidence that approximates that of the nondepletional CD25-specific mAbs (Kirk et al. 2007). This could relate to B-cell depleting properties of alemtuzumab because B cells are the dominant reservoir of EBV. The impact of induction therapy on all-cause mortality remains unclear, especially when combined with newer immunosuppressants for maintenance, as does the risk for increased rejection and malignancy.

\section{Homeostatic Repopulation after Lymphodepletion}

Despite its efficacy in controlling T-cell-mediated acute rejection with low dose maintenance immunosuppression, lymphodepletion alone does not prevent acute rejection in the human patient (Trzonkowski et al. 2006). Turka's group elegantly showed that repopulating $\mathrm{T}$ cells and their phenotypic switching to memory type under homeostatic pressure is a great barrier to promoting tolerance (Wu et al. 2004; Neujahr et al. 2006). Lymphocyte reconstitution involves a dynamic balance between the peripheral expansion of residual lymphocytes and the generation of new lymphocytes from progenitors. Following lymphocytic depletion, homeostatic mechanisms drive the immediate reconstitution of lymphocyte populations whereas lymphopoiesis may not fully impact reconstitution for 1-2 years. Two major components for homeostatic maintenance of lymphocyte numbers and diversity include cytokines/chemokines and survival factors (Marrack et al. 2000; Ploix et al. 2001; Jameson 2002). Continuous engagement of Tcell receptors with self-peptide/MHC-complex is also required for the T-cell homeostatic proliferation (Viret et al. 1999).

T-cell subsets have been increasingly studied in the postdepletion setting, particularly after observing increased Treg populations with alemtuzumab or ATG induction (Ciancio et al. 2005; Bloom et al. 2008; Morelon et al. 2010). The exact mechanism associated with relative or absolute expansion of $\mathrm{CD} 4{ }^{+} \mathrm{CD} 25^{+} \mathrm{T}$ cells remains unclear; however, it is suggested that the increase of Treg is not completely dependent on the sparing of this subset after depletion, but by active conversion of non-Treg to Treg cells (Bloom et al. 2008). This relative increase in Tregs may counter the postdepletional increase in memory-type T cells and their function. Th17 cells also play a role in transplant rejection, as IL-17 has been found in biopsies of rejecting kidney, lung, and liver allografts (Loong et al. 2002; Vanaudenaerde et al. 2008; Fabrega et al. 2009). One study documented an increased number of Th17 with sirolimus monotherapy after alemtuzumab induction (Hester et al. 2011), although its role in rejection after lymphodepletion is unclear. These observations suggest that T-cell subsets have different susceptibilities to depletion and repopulation dynamics.

Follicular helper T cells (Tfh) play a unique role in helping the B-cell response (Crotty 2011). Although little is known on the direct role of Tcell depletion on Tfh cells, our preclinical and clinical studies have reported increased humoral 
Lymphodepletional Strategies

responses and de novo alloantibody production after T-cell depletion (Barth et al. 2006; Page et al. 2012; Kwun et al. 2012b). Tfh cells are known to express high levels of IL-21, which is required for cognate B-cell help and germinal center (GC) formation (Silver and Hunter 2008). Interestingly, increased serum IL-21 levels have been found in a significant subset of multiple sclerosis patients treated with alemtuzumab, which also correlated to their development of autoimmune thyroiditis (Jones et al. 2009). Incomplete depletion in lymph nodes has been previously reported (Kirk et al. 2007; Page et al. 2012); it is possible that lymph node structures provide more resistance to these depletional agents, which may favor an enhanced Tfh cell and germinal center response. Owing to the increasing interest on antibody-mediated rejection in organ transplantation, follicular helper T-cell subsets in lymphodepletion need further careful evaluation.

\section{CONCLUSION}

Lymphodepletion has been an effective strategy for addressing the precursor frequency of alloreactive $T$ cells at the time of organ transplantation and for preventing acute allograft rejection. Several preclinical studies have found that combining lymphodepletion with other modalities may be tolerogenic, although this has yet to be fully achieved in humans. Depletion has allowed, however, for clinicians to decrease maintenance immunosuppression and reduce the side effects of long-term steroids and calcineurin inhibition. For these reasons, it has been an increasingly used method of induction immunosuppression in the United States in recent years. Future studies should evaluate ways to inhibit postdepletional humoral responses and memory $\mathrm{T}$-cell repopulation, while taking care not to over-immunosuppress and subject the patient to infectious and malignant complications.

\section{REFERENCES}

Abbott KC, Hypolite IO, Viola R, Poropatich RK, Hshieh P, Cruess D, Hawkes CA, Agodoa LY. 2002. Hospitalizations for cytomegalovirus disease after renal trans- plantation in the United States. Ann Epidemiol 12: 402-409.

Alexander JW, Goodman HR, Cardi M, Austin J, Goel S, Safdar S, Huang S, Munda R, Fidler JP, Buell JF, et al. 2006. Simultaneous corticosteroid avoidance and calcineurin inhibitor minimization in renal transplantation. Transpl Int 19: 295-302.

Annual Report of the U.S. Organ Procurement and Transplantation Network and the Scientific Registry of Transplant Recipients: Transplant Data 1998-2011. 2011. Department of Health and Human Services, Health Resources and Services Administration, Healthcare Systems Bureau, Division of Transplantation, Rockville, MD; United Network for Organ Sharing, Richmond, VA; University Renal Research and Education Association, Ann Arbor, MI.

Barth RN, Janus CA, Lillesand CA, Radke NA, Pirsch JD, Becker BN, Fernandez LA, Thomas Chin L, Becker YT Odorico JS, et al. 2006. Transpl Int 19: 885-892.

Batiuk TD, Bodziak KA, Goldman M. 2002. Infectious disease prophylaxis in renal transplant patients: A survey of U.S. transplant centers. Clin Transplant 16: 1-8.

Bloom DD, Chang Z, Fechner JH, Dar W, Polster SP, Pascual J, Turka LA, Knechtle SJ. 2008. CD $4^{+} \mathrm{CD}^{2} 5^{+} \mathrm{FOXP}^{+}$ regulatory $\mathrm{T}$ cells increase de novo in kidney transplant patients after immunodepletion with Campath- $1 \mathrm{H}$. Am J Transplant 8: 793-802.

Bloom D, Chang Z, Pauly K, Kwun J, Fechner J, Hayes C, Samaniego M, Knechtle S. 2009. BAFF is increased in renal transplant patients following treatment with alemtuzumab. Am J Transplant 9: 1835-1845.

Boillot O, Seket B, Dumortier J, Pittau G, Boucaud C, Bouffard Y, Scoazec JY. 2009. Thymoglobulin induction in liver transplant recipients with a tacrolimus, mycophenolate mofetil, and steroid immunosuppressive regimen: A five-year randomized prospective study. Liver Transpl 15: 1426-1434.

Bonnefoy-Berard N, Vincent C, Revillard JP. 1991. Antibodies against functional leukocyte surface molecules in polyclonal antilymphocyte and antithymocyte globulins. Transplantation 51: 669-673.

Boulianne GL, Hozumi N, Shulman MJ. 1984. Production of functional chimaeric mouse/human antibody. Nature 312: 643-646.

Bourdage JS, Hamlin DM. 1995. Comparative polyclonal antithymocyte globulin and antilymphocyte/antilymphoblast globulin anti-CD antigen analysis by flow cytometry. Transplantation 59: 1194-1200.

Brennan DC, Schnitzler MA. 2008. Long-term results of rabbit antithymocyte globulin and basiliximab induction. N Engl J Med 359: 1736-1738.

Brennan DC, Daller JA, Lake KD, Cibrik D, Del Castillo D. 2006. Rabbit antithymocyte globulin versus basiliximab in renal transplantation. N Engl J Med 355: 1967-1977.

Calne R, Friend P, Moffatt S, Bradley A, Hale G, Firth J, Bradley J, Smith K, Waldmann H. 1998. Prope tolerance, perioperative campath $1 \mathrm{H}$, and low-dose cyclosporin monotherapy in renal allograft recipients. Lancet 351: 1701-1702.

Calne R, Moffatt SD, Friend PJ, Jamieson NV, Bradley JA, Hale G, Firth J, Bradley J, Smith KG, Waldmann H. 1999. Campath IH allows low-dose cyclosporine monotherapy 
E. Page et al.

in 31 cadaveric renal allograft recipients. Transplantation 68: $1613-1616$.

Chatenoud L, Ferran C, Legendre C, Thouard I, Merite S, Reuter A, Gevaert Y, Kreis H, Franchimont P, Bach JF. 1990. In vivo cell activation following OKT3 administration. Systemic cytokine release and modulation by corticosteroids. Transplantation 49: 697-702.

Cherikh WS, Kauffman HM, McBride MA, Maghirang J, Swinnen LJ, Hanto DW. 2003. Association of the type of induction immunosuppression with posttransplant lymphoproliferative disorder, graft survival, and patient survival after primary kidney transplantation. Transplantation 76: 1289-1293.

Ciancio G, Burke GW, Gaynor JJ, Carreno MR, Cirocco RE, Mathew JM, Mattiazzi A, Cordovilla T, Roth D, Kupin W, et al. 2005. A randomized trial of three renal transplant induction antibodies: Early comparison of tacrolimus, mycophenolate mofetil, and steroid dosing, and newer immune-monitoring. Transplantation 80: 457-465.

Clatworthy MR, Watson CJ, Plotnek G, Bardsley V, Chaudhry AN, Bradley JA, Smith KG. 2009. B-cell-depleting induction therapy and acute cellular rejection. $N$ Engl J Med 360: 2683-2685.

Cosimi AB, Delmonico FL, Wright JK, Wee SL, Preffer FI, Jolliffe LK, Colvin RB. 1990. Prolonged survival of nonhuman primate renal allograft recipients treated only with anti-CD4 monoclonal antibody. Surgery 108: 406-413; discussion 413-404.

Crotty S. 2011. Follicular helper CD4 T cells (TFH). Аnnu Rev Immunol 29: 621-663.

Debets JM, Leunissen KM, van Hooff HJ, van der Linden CJ, Buurman WA. 1989. Evidence of involvement of tumor necrosis factor in adverse reactions during treatment of kidney allograft rejection with antithymocyte globulin. Transplantation 47: 487-492.

Delmonico FL, Cosimi AB, Kawai T, Cavender D, Lee WH, Jolliffe LK, Knowles RW. 1993. Nonhuman primate responses to murine and humanized OKT4A. Transplantation 55: 722-728.

De Simone P, Nevens F, De Carlis L, Metselaar HJ, Beckebaum S, Saliba F, Jonas S, Sudan D, Fung J, Fischer L, et al. 2012. Everolimus with reduced tacrolimus improves renal function in de novo liver transplant recipients: A randomized controlled trial. Am J Transplant 12: 3008 3020.

DiLillo DJ, Hamaguchi Y, Ueda Y, Yang K, Uchida J, Haas KM, Kelsoe G, Tedder TF. 2008. Maintenance of longlived plasma cells and serological memory despite mature and memory $\mathrm{B}$ cell depletion during CD20 immunotherapy in mice. J Immunol 180: 361-371.

DiLillo DJ, Griffiths R, Seshan SV, Magro CM, Ruiz P, Coffman TM, Tedder TF. 2011. B lymphocytes differentially influence acute and chronic allograft rejection in mice. $J$ Immunol 186: 2643-2654.

El-Hamamsy I, Stevens LM, Carrier M, Pelletier G, White M, Tremblay F, Perrault LP. 2005. Incidence and prognosis of cancer following heart transplantation using RATG induction therapy. Transpl Int 18: 1280-1285.

Engram JC, Cervasi B, Borghans JA, Klatt NR, Gordon SN, Chahroudi A, Else JG, Mittler RS, Sodora DL, de Boer RJ et al. 2010. Lineage-specific T-cell reconstitution follow- ing in vivo $\mathrm{CD}^{+}$and $\mathrm{CD} 8^{+}$lymphocyte depletion in nonhuman primates. Blood 116: 748-758.

Fabrega E, Lopez-Hoyos M, San Segundo D, Casafont F, Pons-Romero F. 2009. Changes in the serum levels of interleukin-17/interleukin-23 during acute rejection in liver transplantation. Liver Transpl 15: 629-633.

Feng X, Kajigaya S, Solomou EE, Keyvanfar K, Xu X, Raghavachari N, Munson PJ, Herndon TM, Chen J, Young NS. 2008. Rabbit ATG but not horse ATG promotes expansion of functional $\mathrm{CD} 4{ }^{+} \mathrm{CD} 25^{\text {high }} \mathrm{FOXP}^{+}$regulatory $\mathrm{T}$ cells in vitro. Blood 111: 3675-3683.

Gaber AO, Monaco AP, Russell JA, Lebranchu Y, Mohty M. 2010. Rabbit antithymocyte globulin (thymoglobulin): 25 Years and new frontiers in solid organ transplantation and haematology. Drugs 70: 691-732.

Gourishankar S, McDermid JC, Jhangri GS, Preiksaitis JK. 2004. Herpes zoster infection following solid organ transplantation: Incidence, risk factors and outcomes in the current immunosuppressive era. Am J Transplant 4: 108 115.

Gurk-Turner C, Airee R, Philosophe B, Kukuruga D, Drachenberg C, Haririan A. 2008. Thymoglobulin dose optimization for induction therapy in high risk kidney transplant recipients. Transplantation 85: 1425-1430.

Hale G. 2001. The CD52 antigen and development of the CAMPATH antibodies. Cytotherapy 3: 137-143.

Hanaway MJ, Woodle ES, Mulgaonkar S, Peddi VR, Kaufman DB, First MR, Croy R, Holman J. 2011. Alemtuzumab induction in renal transplantation. $N$ Engl J Med 364: $1909-1919$.

Hardinger KL. 2006. Rabbit antithymocyte globulin induction therapy in adult renal transplantation. Pharmacotherapy 26: 1771-1783.

Heidecke CD, Hancock WW, Jakobs F, Zantl N, Kurrle R, Westerholt S, Sewczik T, Deusch K, Kupiec-Weglinski J. 1995. $\alpha / \beta-$ T cell receptor-directed therapy in rat cardiac allograft recipients. Treatment before alloantigen exposure prevents sensitization and abrogates accelerated rejection. Transplantation 59: 78-84.

Hering BJ, Wijkstrom M, Graham ML, Hardstedt $\mathrm{M}$, Aasheim TC, Jie T, Ansite JD, Nakano M, Cheng J, Li W, et al. 2006. Prolonged diabetes reversal after intraportal xenotransplantation of wild-type porcine islets in immunosuppressed nonhuman primates. Nat Med 12: $301-303$.

Hester J, Mills N, Shankar S, Carvalho-Gaspar M, Friend P, Wood KJ. 2011. Th17 cells in alemtuzumab-treated patients: The effect of long-term maintenance immunosuppressive therapy. Transplantation 91: 744-750.

Hibberd PL, Tolkoff-Rubin NE, Cosimi AB, Schooley RT, Isaacson D, Doran M, Delvecchio A, Delmonico FL, Auchincloss H Jr, Rubin RH. 1992. Symptomatic cytomegalovirus disease in the cytomegalovirus antibody seropositive renal transplant recipient treated with OKT3. Transplantation 53: 68-72.

Hirohashi T, Chase CM, Della Pelle P, Sebastian D, Alessandrini A, Madsen JC, Russell PS, Colvin RB. 2012. A novel pathway of chronic allograft rejection mediated by NK cells and alloantibody. Am J Transplant 12: 313-321.

Hirshberg B, Preston EH, Xu H, Tal MG, Neeman Z, Bunnell D, Soleimanpour S, Hale DA, Kirk AD, Harlan DM. 2003. Rabbit antithymocyte globulin induction and sirolimus 
Lymphodepletional Strategies

monotherapy supports prolonged islet allograft function in a nonhuman primate islet transplantation model. Transplantation 76: 55-60.

Hongo D, Tang X, Dutt S, Nador RG, Strober S. 2012. Interactions between NKT cells and Tregs are required for tolerance to combined bone marrow and organ transplants. Blood 119: 1581-1589.

Jameson SC. 2002. Maintaining the norm: T-cell homeostasis. Nat Rev Immunol 2: 547-556.

Jones JL, Phuah CL, Cox AL, Thompson SA, Ban M, Shawcross J, Walton A, Sawcer SJ, Compston A, Coles AJ. 2009. IL-21 drives secondary autoimmunity in patients with multiple sclerosis, following therapeutic lymphocyte depletion with alemtuzumab (Campath-1H). J Clin Invest 119: $2052-2061$.

Jonker M, Goldstein G, Balner H. 1983. Effects of in vivo administration of monoclonal antibodies specific for human $\mathrm{T}$ cell subpopulations on the immune system in a rhesus monkey model. Transplantation 35: 521-526.

Joseph A, Neff K, Richard J, Gao L, Bangari D, Joly M, CulmMerdek K, Garman R, Williams J, Richards S, et al. 2012. Transient low-dose methotrexate induces tolerance to murine anti-thymocyte globulin and together they promote long-term allograft survival. J Immunol 189: 732743.

Kaplon RJ, Hochman PS, Michler RE, Kwiatkowski PA, Edwards NM, Berger CL, Xu H, Meier W, Wallner BP, Chisholm P, et al. 1996. Short course single agent therapy with an LFA-3-IgG1 fusion protein prolongs primate cardiac allograft survival. Transplantation 61: 356-363.

Kawai T, Cosimi AB, Colvin RB, Powelson J, Eason J, Kozlowski T, Sykes M, Monroy R, Tanaka M, Sachs DH. 1995. Mixed allogeneic chimerism and renal allograft tolerance in cynomolgus monkeys. Transplantation 59: 256-262.

Kawai T, Sogawa H, Boskovic S, Abrahamian G, Smith RN, Wee SL, Andrews D, Nadazdin O, Koyama I, Sykes M, et al. 2004. CD154 blockade for induction of mixed chimerism and prolonged renal allograft survival in nonhuman primates. Am J Transplant 4: 1391-1398.

Kelishadi SS, Azimzadeh AM, Zhang T, Stoddard T, Welty E, Avon C, Higuchi M, Laaris A, Cheng XF, McMahon C, et al. 2010. Preemptive CD20 ${ }^{+} \mathrm{B}$ cell depletion attenuates cardiac allograft vasculopathy in cyclosporine-treated monkeys. J Clin Invest 120: 1275-1284.

Kim GB, Wang Z, Liu YY, Stavrou S, Mathias A, Goodwin KJ, Thomas JM, Neville DM. 2007. A fold-back singlechain diabody format enhances the bioactivity of an anti-monkey CD3 recombinant diphtheria toxin-based immunotoxin. Protein Eng Des Sel 20: 425-432.

Kirk AD, Hale DA, Mannon RB, Kleiner DE, Hoffmann SC, Kampen RL, Cendales LK, Tadaki DK, Harlan DM, Swanson SJ. 2003. Results from a human renal allograft tolerance trial evaluating the humanized CD52-specific monoclonal antibody alemtuzumab (CAMPATH-1H). Transplantation 76: 120-129.

Kirk AD, Cherikh WS, Ring M, Burke G, Kaufman D, Knechtle SJ, Potdar S, Shapiro R, Dharnidharka VR, Kauffman HM. 2007. Dissociation of depletional induction and posttransplant lymphoproliferative disease in kidney recipients treated with alemtuzumab. Am J Transplant 7: 2619-2625.
Kirk AD, Mead S, Xu H, Mehta A, Guasch A, Cheeseman J, Joseph J, Horan J, Kean L, Larsen CP, et al. 2011. Kidney transplantation using alemtuzumab induction and belatacept/sirolimus maintenance therapy. Am J Transplant 11: 45 .

Knechtle SJ. 2001. Treatment with immunotoxin. Philos Trans R Soc London B Biol Sci 356: 681-689.

Knechtle SJ, Vargo D, Fechner J, Zhai Y, Wang J, Hanaway MJ, Scharff J, Hu H, Knapp L, Watkins D, et al. 1997. FN18-CRM9 immunotoxin promotes tolerance in primate renal allografts. Transplantation 63: 1-6.

Knechtle SJ, Fechner JH Jr, Dong Y, Stavrou S, Neville DM Jr, Oberley T, Buckley P, Armstrong N, Rusterholz K, Hong $\mathrm{X}$, et al. 1998. Primate renal transplants using immunotoxin. Surgery 124: 438-446; discussion 446-437.

Koyama I, Nadazdin O, Boskovic S, Ochiai T, Smith RN, Sykes M, Sogawa H, Murakami T, Strom TB, Colvin RB, et al. 2007. Depletion of CD8 memory T cells for induction of tolerance of a previously transplanted kidney allograft. Am J Transplant 7: 1055-1061.

Kung P, Goldstein G, Reinherz EL, Schlossman SF. 1979. Monoclonal antibodies defining distinctive human T cell surface antigens. Science 206: 347-349.

Kwun J, Bulut P, Kim E, Dar W, Oh B, Ruhil R, Iwakoshi N, Knechtle SJ. 2012a. The role of B cells in solid organ transplantation. Semin Immunol 24: 96-108.

Kwun J, Oh BC, Gibby AC, Ruhil R, Lu VT, Kim DW, Page EK, Bulut OP, Song MQ, Farris AB, et al. 2012b. Patterns of de novo allo B cells and antibody formation in chronic cardiac allograft rejection after alemtuzumab treatment. Am J Transplant 12: 2641-2651.

Letvin NL, Ritz J, Guida LJ, Yetz JM, Lambert JM, Reinherz EL, Schlossman SF. 1985. In vivo administration of lymphocyte-specific monoclonal antibodies in nonhuman primates: I. Effects of anti-T11 antibodies on the circulating T cell pool. Blood 66: 961-966.

Lin WY, Gong Q, Seshasayee D, Lin Z, Ou Q, Ye S, Suto E, Shu J, Lee WP, Lee CW, et al. 2007. Anti-BR3 antibodies: A new class of B-cell immunotherapy combining cellular depletion and survival blockade. Blood 110: 3959-3967.

Liu C, Noorchashm H, Sutter JA, Naji M, Prak EL, Boyer J, Green T, Rickels MR, Tomaszewski JE, Koeberlein B, et al. 2007. B lymphocyte-directed immunotherapy promotes long-term islet allograft survival in nonhuman primates. Nat Med 13: 1295-1298.

Loong CC, Hsieh HG, Lui WY, Chen A, Lin CY. 2002. Evidence for the early involvement of interleukin $17 \mathrm{in} \mathrm{hu-}$ man and experimental renal allograft rejection. J Pathol 197: $322-332$

Luo H, Wu Y, Qi S, Wan X, Chen H, Wu J. 2001. A proteasome inhibitor effectively prevents mouse heart allograft rejection. Transplantation 72: 196-202.

Ma S, Hu H, Thompson J, Stavrou S, Scharff J, Neville DM Jr. 1997. Genetic construction and characterization of an anti-monkey CD3 single-chain immunotoxin with a truncated diphtheria toxin. Bioconjug Chem 8: 695-701.

Magliocca JF, Knechtle SJ. 2006. The evolving role of alemtuzumab (Campath-1H) for immunosuppressive therapy in organ transplantation. Transpl Int 19: 705-714.

Maki T, Carville A, Stillman IE, Sato K, Kodaka T, Minamimura K, Ogawa N, Kanamoto A, Gottschalk R, Monaco 
E. Page et al.

AP, et al. 2008. SV40 infection associated with rituximab treatment after kidney transplantation in nonhuman primates. Transplantation 85: 893-902.

Malatack JF, Gartner JC Jr, Urbach AH, Zitelli BJ. 1991. Orthotopic liver transplantation, Epstein-Barr virus, cyclosporine, and lymphoproliferative disease: A growing concern. J Pediatr 118: 667-675.

Marcos A, Eghtesad B, Fung JJ, Fontes P, Patel K, Devera M, Marsh W, Gayowski T, Demetris AJ, Gray EA, et al. 2004 Use of alemtuzumab and tacrolimus monotherapy for cadaveric liver transplantation: With particular reference to hepatitis $C$ virus. Transplantation 78: 966-971.

Marrack P, Bender J, Hildeman D, Jordan M, Mitchell T, Murakami M, Sakamoto A, Schaefer BC, Swanson B, Kappler J. 2000. Homeostasis of $\alpha \beta \mathrm{TCR}^{+} \mathrm{T}$ cells. Nat Immunol 1: 107-111.

McGregor CG, Davies WR, Oi K, Teotia SS, Schirmer JM, Risdahl JM, Tazelaar HD, Kremers WK, Walker RC, Byrne GW, et al. 2005. Cardiac xenotransplantation: Recent preclinical progress with 3-month median survival. J Thoracic Cardio Surgery 130: 844-851.

Meier-Kriesche HU, Arndorfer JA, Kaplan B. 2002. Association of antibody induction with short- and long-term cause-specific mortality in renal transplant recipients. J Am Soc Nephrol 13: 769-772.

Mohty M. 2007. Mechanisms of action of antithymocyte globulin: T-cell depletion and beyond. Leukemia 21: 1387-1394.

Morelon E, Lefrancois N, Besson C, Prevautel J, Brunet M, Touraine JL, Badet L, Touraine-Moulin F, Thaunat O, Malcus C. 2010. Preferential increase in memory and regulatory subsets during T-lymphocyte immune reconstitution after thymoglobulin induction therapy with maintenance sirolimus vs cyclosporine. Transplant Immunol 23: 53-58.

Morrison SL, Johnson MJ, Herzenberg LA, Oi VT. 1984. Chimeric human antibody molecules: mouse antigenbinding domains with human constant region domains. Proc Natl Acad Sci 81: 6851-6855.

Mossner E, Brunker P, Moser S, Puntener U, Schmidt C, Herter S, Grau R, Gerdes C, Nopora A, van Puijenbroek E, et al. 2010. Increasing the efficacy of CD20 antibody therapy through the engineering of a new type II antiCD20 antibody with enhanced direct and immune effector cell-mediated B-cell cytotoxicity. Blood 115: 4393 4402.

Najarian JS, Simmons RL. 1971. The clinical use of antilymphocyte globulin. N Engl J Med 285: 158-166.

Nath DS, Kandaswamy R, Gruessner R, Sutherland DE, Dunn DL, Humar A. 2005. Fungal infections in transplant recipients receiving alemtuzumab. Transplant Proc 37: 934-936.

Neujahr DC, Chen C, Huang X, Markmann JF, Cobbold S, Waldmann H, Sayegh MH, Hancock WW, Turka LA 2006. Accelerated memory cell homeostasis during T cell depletion and approaches to overcome it. J Immunol 176: $4632-4639$.

Neville DM Jr, Scharff J, Srinivasachar K. 1992. In vivo T-cell ablation by a holo-immunotoxin directed at human CD3. Proc Natl Acad Sci 89: 2585-2589.

Nicolls MR, Aversa GG, Pearce NW, Spinelli A, Berger MF, Gurley KE, Hall BM. 1993. Induction of long-term specific tolerance to allografts in rats by therapy with an anti-CD3-like monoclonal antibody. Transplantation 55: 459-468.

Nishimura H, Scalea J, Wang Z, Shimizu A, Moran S, Gillon B, Sachs DH, Yamada K. 2011. First experience with the use of a recombinant $\mathrm{CD} 3$ immunotoxin as induction therapy in pig-to-primate xenotransplantation: The effect of T-cell depletion on outcome. Transplantation 92: 641-647.

Opelz G. 1995. Efficacy of rejection prophylaxis with OKT3 in renal transplantation. Collaborative Transplant Study. Transplantation 60: 1220-1224.

Orlando G, Hematti P, Stratta RJ, Burke GW 3rd, Di Cocco P, Pisani F, Soker S, Wood K. 2010. Clinical operational tolerance after renal transplantation: Current status and future challenges. Ann Surg 252: 915-928.

Orosz CG, Wakely E, Bergese SD, VanBuskirk AM, Ferguson RM, Mullet D, Apseloff G, Gerber N. 1996. Prevention of murine cardiac allograft rejection with gallium nitrate. Comparison with anti-CD4 monoclonal antibody. Transplantation 61: 783-791.

Page EK, Page AJ, Kwun J, Gibby AC, Leopardi F, Jenkins JB, Strobert EA, Song M, Hennigar RA, Iwakoshi N, et al. 2012. Enhanced de novo alloantibody and antibody-mediated injury in rhesus macaques. Am J Transplant 12: 2395-2405.

Pearl JP, Parris J, Hale DA, Hoffmann SC, Bernstein WB, McCoy KL, Swanson SJ, Mannon RB, Roederer M, Kirk AD. 2005. Immunocompetent T-cells with a memorylike phenotype are the dominant cell type following antibody-mediated T-cell depletion. Am J Transplant 5: 465-474.

Pearl JP, Xu H, Leopardi F, Preston E, Kirk AD. 2007. CD154 blockade, sirolimus, and donor-specific transfusion prevents renal allograft rejection in cynomolgus monkeys despite homeostatic T-cell activation. Transplantation 83: $1219-1225$.

Pearson TC, Bushell AR, Darby CR, West LJ, Morris PJ, Wood KJ. 1993. Lymphocyte changes associated with prolongation of cardiac allograft survival in adult mice using anti-CD4 monoclonal antibody. Clin Exp Immunol 92: $211-217$.

Pearson TC, Trambley J, Odom K, Anderson DC, Cowan S, Bray R, Lin A, Hollenbaugh D, Aruffo A, Siadak AW, et al. 2002. Anti-CD40 therapy extends renal allograft survival in rhesus macaques. Transplantation 74: 933-940.

Penn I. 1990. Cancers complicating organ transplantation. N Engl J Med 323: 1767-1769.

Ploix C, Lo D, Carson MJ. 2001. A ligand for the chemokine receptor CCR7 can influence the homeostatic proliferation of CD4 T cells and progression of autoimmunity. $J$ Immunol 167: 6724-6730.

Preville X, Flacher M, LeMauff B, Beauchard S, Davelu P, Tiollier J, Revillard JP. 2001. Mechanisms involved in antithymocyte globulin immunosuppressive activity in a nonhuman primate model. Transplantation 71: 460468.

Prin Mathieu C, Renoult E, Kennel De March A, Bene MC, Kessler M, Faure GC. 1997. Serum anti-rabbit and antihorse IgG, IgA, and IgM in kidney transplant recipients. Nephrol Dial Transplant 12: 2133-2139. 
Quesniaux V, Fullard L, Arendse H, Davison G, Markgraaff N, Auer R, Ehrhart F, Kraus G, Schuurman HJ. 1999. A novel immunosuppressant, FTY720, induces peripheral lymphodepletion of both Tand B cells and immunosuppression in baboons. Transplant Immunol 7: 149-157.

Quesniaux VF, Menninger K, Kunkler A, Vedrine C, Bernhard M, Hedinger R, Kraus G, Schuurman HJ. 2000. The novel immunosuppressant FTY720 induces peripheral lymphodepletion of both $\mathrm{T}$ and $\mathrm{B}$ cells in cynomolgus monkeys when given alone, with Cyclosporine Neoral or with RAD. Transplant Immunol 8: 177-187.

Rao PE, Olini G, Kille J, Muchmore E, Talle MA, Brake G, Rudnick SA. 1991. OKT3E, an anti-CD3 antibody that does not elicit side effects or antiidiotype responses in chimpanzees. Transplantation 52: 691-697.

Rebellato LM, Gross U, Verbanac KM, Thomas JM. 1994. A comprehensive definition of the major antibody specificities in polyclonal rabbit antithymocyte globulin. Transplantation 57: 685-694.

Redfield RR II, Rodriguez E, Parsons R, Vivek K, Mustafa MM, Noorchashm H, Naji A. 2011. Essential role for B cells in transplantation tolerance. Curr Opin Immunol 23: 685-691.

Regan J, Campbell K, van Smith L, Pouletty P, Schroeder TJ, Guttmann RD, Buelow R. 1997. Characterization of antithymoglobulin, anti-Atgam and anti-OKT3 IgG antibodies in human serum with an 11-min ELISA. Transplant Immunol 5: 49-56.

Regan JF, Lyonnais C, Campbell K, Smith LV, Buelow R. 2001. Total and active thymoglobulin levels: Effects of dose and sensitization on serum concentrations. Transplant Immunol 9: 29-36.

Ruhil R, Oh B, Lu VT, Bulut P, Kwun J, Talebagha S, Knechtle S, Iwakoshi N. 2012. Tacrolimus inhibits alloantibody and plasma cell development but permits germinal center reaction and accumulation of memory B cells: Implications for humoral rejection. Am J Transplant 12: 53.

Schroeder TJ, First MR, Mansour ME, Hurtubise PE, Hariharan S, Ryckman FC, Munda R, Melvin DB, Penn I Ballistreri WF, et al. 1990. Antimurine antibody formation following OKT3 therapy. Transplantation 49: 48-51.

Schuurman HJ, Menninger K, Audet M, Kunkler A, Maurer C, Vedrine C, Bernhard M, Gaschen L, Brinkmann V, Quesniaux V. 2002. Oral efficacy of the new immunomodulator FTY720 in cynomolgus monkey kidney allotransplantation, given alone or in combination with cyclosporine or RAD. Transplantation 74: 951-960.

Shapiro R, Ellis D, Tan HP, Moritz ML, Basu A, Vats AN, Kayler LK, Erkan E, McFeaters CG, James G, et al. 2007. Alemtuzumab pre-conditioning with tacrolimus monotherapy in pediatric renal transplantation. Am J Transplant 7: 2736-2738.

Shapiro R, Zeevi A, Basu A, Tan HP, Kayler LK, Blisard DM, Thai NL, Girnita AL, Randhawa PS, Gray EA, et al. 2008. Alemtuzumab preconditioning with tacrolimus monotherapy-The impact of serial monitoring for donorspecific antibody. Transplantation 85: 1125-1132.

Shi Q, Lees JR, Scott DW, Farber DL, Bartlett ST. 2012. Endogenous expansion of regulatory $\mathrm{T}$ cells leads to long-term islet graft survival in diabetic NOD mice. Am J Transplant 12: 1124-1132.
Sido B, Dengler TJ, Otto G, Zimmermann R, Muller P, Meuer SC. 1998. Differential immunosuppressive activity of monoclonal CD2 antibodies on allograft rejection versus specific antibody production. Eur J Immunol 28: 1347-1357.

Silver JS, Hunter CA. 2008. With a little help from their friends: interleukin-21, T cells, and B cells. Immunity 29: 7-9.

Starzl TE, Marchioro TL, Waddell WR. 1963. The reversal of rejection in human renal homografts with subsequent development of homograft tolerance. Surg Gynecol Obstet 117: 385-395.

Starzl TE, Marchioro TL, Hutchinson DE, Porter KA, Cerilli GJ, Brettschneider L. 1967. The clinical use of antilymphocyte globulin in renal homotransplantation. Transplantation 5: 1100-1105.

Starzl TE, Murase N, Abu-Elmagd K, Gray EA, Shapiro R, Eghtesad B, Corry RJ, Jordan ML, Fontes P, Gayowski T, et al. 2003. Tolerogenic immunosuppression for organ transplantation. Lancet 361: 1502-1510.

Swanson SJ, Hale DA, Mannon RB, Kleiner DE, Cendales LC, Chamberlain CE, Polly SM, Harlan DM, Kirk AD. 2002. Kidney transplantation with rabbit antithymocyte globulin induction and sirolimus monotherapy. Lancet 360: $1662-1664$

Swinnen LJ, Costanzo-Nordin MR, Fisher SG, O'Sullivan EJ, Johnson MR, Heroux AL, Dizikes GJ, Pifarre R, Fisher RI. 1990. Increased incidence of lymphoproliferative disorder after immunosuppression with the monoclonal antibody OKT3 in cardiac-transplant recipients. $N$ Engl J Med 323: 1723-1728.

Tang Q, Smith JA, Szot GL, Zhou P, Alegre ML, Henriksen KJ, Thompson CB, Bluestone JA. 2003. CD28/B7 regulation of anti-CD3-mediated immunosuppression in vivo. J Immunol 170: 1510-1516.

Thomas FT, Carver FM, Foil MB, Pryor WH, Larkin EW, Hall WR, Haisch CE, Thomas JM. 1983. Long-term incompatible kidney survival in outbred higher primates without chronic immunosuppression. Ann Surg 198: 370378.

Thomas JM, Carver M, Cunningham P, Sash C, Park K, Thomas F. 1989. Promotion of incompatible allograft acceptance in rhesus monkeys given posttransplant antithymocyte globulin and donor bone marrow. II. Effects of adjuvant immunosuppressive drugs. Transplantation 47: 209-215.

Thompson P, Badell IR, Lowe M, Turner A, Cano J, Avila J, Azimzadeh A, Cheng X, Pierson RN 3rd, Johnson B, et al. 2012. Alternative immunomodulatory strategies for xenotransplantation: $\mathrm{CD} 40 / 154$ pathway-sparing regimens promote xenograft survival. Am J Transplant 12: $1765-$ 1775 .

Torrealba JR, Fernandez LA, Kanmaz T, Oberley TD, Schultz JM, Brunner KG, Peters D, Fechner JH Jr, Dong Y, Hu H, et al. 2003. Immunotoxin-treated rhesus monkeys: A model for renal allograft chronic rejection. Transplantation 76: 524-530.

Torrealba JR, Katayama M, Fechner JH Jr, Jankowska-Gan E, Kusaka S, Xu Q, Schultz JM, Oberley TD, Hu H, Hamawy $\mathrm{MM}$, et al. 2004. Metastable tolerance to rhesus monkey renal transplants is correlated with allograft TGF- $\beta 1^{+}$ 
E. Page et al.

$\mathrm{CD} 4^{+}$T regulatory cell infiltrates. J Immunol 172: $5753-$ 5764.

Trzonkowski P, Zilvetti M, Friend P, Wood KJ. 2006. Recipient memory-like lymphocytes remain unresponsive to graft antigens after CAMPATH-1H induction with reduced maintenance immunosuppression. Transplantation 82: 1342-1351.

Vallhonrat H, Williams WW, Cosimi AB, Tolkoff-Rubin N, Ginns LC, Wain JC, Preffer F, Olszak I, Wee S, Delmonico $\mathrm{FL}$, et al. 1999. In vivo generation of $\mathrm{C} 4 \mathrm{~d}, \mathrm{Bb}, \mathrm{iC} 3 \mathrm{~b}$, and SC5b-9 after OKT3 administration in kidney and lung transplant recipients. Transplantation 67: 253-258.

Vanaudenaerde BM, De Vleeschauwer SI, Vos R, Meyts I, Bullens DM, Reynders V, Wuyts WA, Van Raemdonck DE, Dupont LJ, Verleden GM. 2008. The role of the IL23/IL17 axis in bronchiolitis obliterans syndrome after lung transplantation. Am J Transplant 8: 1911-1920.

van der Touw W, Burrell B, Lal G, Bromberg JS. 2012. NK Cells are required for costimulatory blockade induced tolerance to vascularized allografts. Transplantation 94: 575-584.

van der Windt DJ, Smetanka C, Macedo C, He J, Lakomy R, Bottino R, Ekser B, Echeverri GJ, Metes D, Ijzermans JN, et al. 2010. Investigation of lymphocyte depletion and repopulation using alemtuzumab (Campath-1H) in cynomolgus monkeys. Am J Transplant 10: 773-783.

Viret C, Wong FS, Janeway CA Jr, 1999. Designing and maintaining the mature TCR repertoire: The continuum of self-peptide:self-MHC complex recognition. Immunity 10: $559-568$.

Vivier E, Tomasello E, Baratin M, Walzer T, Ugolini S. 2008. Functions of natural killer cells. Nat Immunol 9: 503510.

Wang Z, Duran-Struuck R, Crepeau R, Matar A, Hanekamp I, Srinivasan S, Neville DM Jr, Sachs DH, Huang CA. 2011. Development of a diphtheria toxin based antiporcine CD3 recombinant immunotoxin. Bioconjug Chem 22: 2014-2020.
Watson CJ, Bradley JA, Friend PJ, Firth J, Taylor CJ, Bradley JR, Smith KG, Thiru S, Jamieson NV, Hale G, et al. 2005. Alemtuzumab (CAMPATH $1 \mathrm{H}$ ) induction therapy in cadaveric kidney transplantation-efficacy and safety at five years. Am J Transplant 5: 1347-1353.

Weaver TA, Charafeddine AH, Agarwal A, Turner AP, Russell M, Leopardi FV, Kampen RL, Stempora L, Song M, Larsen CP, et al. 2009. Alefacept promotes co-stimulation blockade based allograft survival in nonhuman primates. Nat Med 15: 746-749.

Webster AC, Pankhurst T, Rinaldi F, Chapman JR, Craig JC. 2006. Monoclonal and polyclonal antibody therapy for treating acute rejection in kidney transplant recipients: A systematic review of randomized trial data. Transplantation 81: 953-965.

Wijkstrom M, Kenyon NS, Kirchhof N, Kenyon NM, Mullon C, Lake P, Cottens S, Ricordi C, Hering BJ. 2004. Islet allograft survival in nonhuman primates immunosuppressed with basiliximab, RAD, and FTY720. Transplantation 77: 827-835.

Woodle ES, Thistlethwaite JR, Jolliffe LK, Zivin RA, Collins A, Adair JR, Bodmer M, Athwal D, Alegre ML, Bluestone JA. 1992. Humanized OKT3 antibodies: Successful transfer of immune modulating properties and idiotype expression. J Immunol 148: 2756-2763.

Wu Z, Bensinger SJ, Zhang J, Chen C, Yuan X, Huang X, Markmann JF, Kassaee A, Rosengard BR, Hancock WW, et al. 2004. Homeostatic proliferation is a barrier to transplantation tolerance. Nat Med 10: 87-92.

Yi H, Zhen Y, Zeng C, Zhang L, Zhao Y. 2008. Depleting anti-CD4 monoclonal antibody (GK1.5) treatment: Influence on regulatory $\mathrm{CD} 4{ }^{+} \mathrm{CD} 25^{+} \mathrm{Foxp}^{+} \mathrm{T}$ cells in mice. Transplantation 85: 1167-1174.

Zalevsky J, Leung IW, Karki S, Chu SY, Zhukovsky EA, Desjarlais JR, Carmichael DF, Lawrence CE. 2009. The impact of Fc engineering on an anti-CD19 antibody: Increased $\mathrm{Fc} \gamma$ receptor affinity enhances B-cell clearing in nonhuman primates. Blood 113: 3735-3743. 


\section{$\&_{\mathrm{CSH}}^{\infty} \&$ Cold Spring Harbor

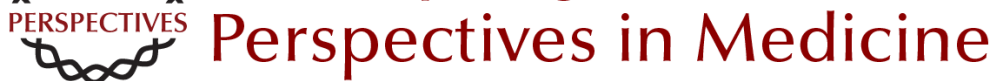

\section{Lymphodepletional Strategies in Transplantation}

Eugenia Page, Jean Kwun, Byoungchol Oh and Stuart Knechtle

Cold Spring Harb Perspect Med 2013; doi: 10.1101/cshperspect.a015511

Subject Collection Transplantation

Heart Transplantation: Challenges Facing the

Field

Makoto Tonsho, Sebastian Michel, Zain Ahmed, et al.

Bioethics of Organ Transplantation Arthur Caplan

Overview of Clinical Lung Transplantation Jonathan C. Yeung and Shaf Keshavjee

Immunological Challenges and Therapies in

Xenotransplantation Marta Vadori and Emanuele Cozzi

Clinical Aspects: Focusing on Key Unique Organ-Specific Issues of Renal Transplantation Sindhu Chandran and Flavio Vincenti

T-Cell Costimulatory Blockade in Organ

Transplantation Jonathan S. Maltzman and Laurence A. Turka

Regulatory T-Cell Therapy in Transplantation:

Moving to the Clinic

Qizhi Tang and Jeffrey A. Bluestone

Opportunistic Infections--Coming to the Limits of Immunosuppression?

Jay A. Fishman
Overview of the Indications and Contraindications

for Liver Transplantation

Stefan Farkas, Christina Hackl and Hans Jürgen Schlitt

Facial and Hand Allotransplantation Bohdan Pomahac, Ryan M. Gobble and Stefan Schneeberger

Induction of Tolerance through Mixed Chimerism David H. Sachs, Tatsuo Kawai and Megan Sykes

Pancreas Transplantation: Solid Organ and Islet Shruti Mittal, Paul Johnson and Peter Friend

Tolerance--Is It Worth It? Erik B. Finger, Terry B. Strom and Arthur J. Matas

Lessons and Limits of Mouse Models Anita S. Chong, Maria-Luisa Alegre, Michelle L. Miller, et al.

Effector Mechanisms of Rejection Aurélie Moreau, Emilie Varey, Ignacio Anegon, et al.

The Innate Immune System and Transplantation Conrad A. Farrar, Jerzy W. Kupiec-Weglinski and Steven H. Sacks

For additional articles in this collection, see http://perspectivesinmedicine.cshlp.org/cgi/collection/ 